\title{
THE INFLUENCE OF WORKING CONDITIONS, HEALTH STATUS AND CHARACTERISTICS OF WORKERS ON THE OCCURRENCE OF WORKPLACE INJURIES
}

\author{
Jovana Jovanović1 ${ }^{\text {, Ivana Šarac }}{ }^{2}$, Nataša Đinđići ${ }^{1}$ \\ Stefan Jovanović ${ }^{1}$
}

\begin{abstract}
Workplace injuries represent an important medical, social and economic burden. The aim of this study was to analyze the impact of harmful workplace conditions and gender, age and other characteristics of workers, on the occurrence of workplace injuries. The studied (case) group included 1950 workers who had at least one workplace injury in the period of one year (January-December, 2011). The control group consisted of 1450 workers who had no workplace injuries in the same period of time, and who had similar jobs (factory workers). For both groups, hazards and risks were measured at their workplaces (microclimate factors, illumination, noise, dust, air pollution, chemical hazards). For all workers, the data about gender, age, total length of employment, work characteristics, education, marital status were collected, as well as their working, personal, family and social anamnesis, and detailed clinical examination and additional analyses (laboratory, electrocardiography, spirometry, audiometry and anthropometry) were performed. There was a higher prevalence of neuroses, arterial hypertension, eye diseases, hearing disturbances, and overweight and obesity in the exposed group compared to controls. The factors such as inadequate working conditions, younger age of workers, less working experience, lower level of education, and presence of specific health conditions and diseases, are significantly related to the occurrence of workplace injuries.
\end{abstract} Acta Medica Medianae 2017;56(4):17-24. condition

Key words: workplace injury, noise, air pollution, professional risk, worker health

${ }^{1}$ University of Niš, Faculty of Medicine, Niš, Serbia

${ }^{2}$ Institute of occupational health Niš, Serbia

Contact: Jovana Jovanović

Bul. dr Zorana Đinđića 81, 18000 Niš, Serbia

E-mail: jovana88nis@gmail.com

\section{Introduction}

Workplace injuries are a regular accompaniment of any human work and represent an important health, social, and economic burden in the modern society. Their consequences influence not only the injured workers but also their fami- lies, companies, and the entire society. Life and health threats and injuries, reductions or loss of working capability, financial costs because of compensations for deaths and sick-leaves, medical treatments, rehabilitations and invalidities, reductions in life activities, family disturbances, perturbations of working processes, reductions in productivity and quality of work, make the problem of work traumatism very significant $(1,2,3)$. It is considered that work traumatism is the leading cause of death in the population up to 37 years old and for the entire population it is at the third place, after cardiovascular and malignant diseases $(4,5)$. The consequence of an injury can be death, severe or non-severe physical health damage and diseases, mental health disorders or diseases, and acute and chronic physical pain $(6,7,8)$. Deteriorations of mental and physical health after an injury can have temporary or permanent consequences $(9,10,11)$. Therefore, the assessment of contributing factors in the development of workplace injuries is very important for worker and employer education and vigilance, adequate training and health promotion at work, development of preventive measures, which leads to the reduced rates of future work traumatism or, at least, alleviation of its consequences $(12,13)$. 


\section{Aim}

The aim of the study was to analyse the impact of workplace hazards and characteristics, and health condition of workers on the occurrence of workplace injuries.

\section{Methods}

Two groups of workers were followed. The exposed group comprised 1950 workers who during a period of one year (January - December 2011) had at least one injury. The control group consisted of 1450 workers who in the same period of time had no workplace injuries, and who had similar jobs (factory workers).

In both groups, workplace conditions and presence of workplace hazards (microclimatic factors, illumination, noise, dust, air pollution, chemical hazards) were analysed. For all workers, the data on gender, age, work characteristics, total length of employment, education, marital status were collected, as well as their working, personal, family, and social anamnesis. In addition, a detailed clinical examination was performed by a multidisciplinary team (occupational health specialist, psychologist, neuropsychiatrist, ophthalmologist, otorhinolaryngologist), and additional analyses were performed as well, including laboratory, electrocardiography, spirometry, audiometry, and anthropometry. Body mass index (BMI) was calculated according to the formula: BMI = body mass $(\mathrm{kg}) /$ height $(\mathrm{m})^{2}$, where values 18.5-24.9 $\mathrm{kg} / \mathrm{m}^{2}$ were considered as "normal weight", values under $18,4 \mathrm{~kg} / \mathrm{m}^{2}$ were considered as "underweight", and values above $25.0 \mathrm{~kg} / \mathrm{m}^{2}$ were considered as "overweight and obese".

The data for the analysis of workplace in- juries were "workplace injury reports", filled by an occupational safety officer and a medical doctor who was the first to make a medical examination after one workplace injury.

Statistical significance of the examined parameters between the "case" and "control" group was analysed by the use of the Student's t-test and $\mathrm{X}^{2}$ test.

\section{Results}

The workers in the case group were younger and had less working experience, compared with the control group (Table 1). The workers in the case group were more exposed to negative work-

Table 1. Age and working experience of workers in the "case" and "control" group

\begin{tabular}{||c||c|c||}
\hline & $\begin{array}{c}\text { "Case" } \\
\text { group } \\
\mathrm{N}=1950\end{array}$ & $\begin{array}{c}\text { "Control" } \\
\text { group } \\
\mathrm{N}=1450\end{array}$ \\
\hline \hline Age (years) & $27.3 \pm 2.7 *$ & $39.9 \pm 5.4$ \\
\hline $\begin{array}{c}\text { Working experience } \\
\text { (years) }\end{array}$ & $1.1 \pm 0.3 *$ & $6.7 \pm 0.4$ \\
\hline
\end{tabular}

place microclimatic conditions, noise, dust, chemical hazards, air pollution, and inadequate illumination (Table 2), while for the workers in the control group the measured values of these parameters were within the allowed reference limits (Table 3 ). The case and control groups were different regarding the level of education: there were more "laborers" (unskilled workers) and less university level workers in the case group (Table 4). There were no differences between the case and control groups in gender, marital status, cigarette smoking, alcohol consumption, shift work, night work, and work in production quotas (Table 4). Over-

Table 2. Workplace hazards in the "case" group

\begin{tabular}{|c|c|c|c|}
\hline \multicolumn{4}{|c|}{ Type of workplace hazards } \\
\hline & & Measured values & Allowed values \\
\hline \multirow{4}{*}{$\begin{array}{l}\text { Microclimatic } \\
\text { factors }\end{array}$} & \multirow{2}{*}{ Air temperature $\left({ }^{\circ} \mathrm{C}\right)$} & $\begin{array}{c}10.2 \pm 1.4 \\
\text { Winter }\end{array}$ & \multirow{2}{*}{$15-22$} \\
\hline & & $\begin{array}{c}29.8 \pm 8.7 \\
\text { Summer }\end{array}$ & \\
\hline & Air relative humidity $(\%)$ & $63.3 \pm 15.8$ & $30-60$ \\
\hline & Air velocity $(\mathrm{m} / \mathrm{s})$ & $0.7 \pm 1.2$ & under 0.5 \\
\hline \multicolumn{2}{|r|}{ Illumination (Lux) } & $74.8 \pm 4.7$ & $80-150$ \\
\hline \multicolumn{2}{|r|}{ Noise $(\mathrm{dB})$} & $99.8 \pm 15.7$ & under 85 \\
\hline \multicolumn{2}{|r|}{ Dust $\left(\mathrm{mg} / \mathrm{m}^{3}\right)$} & $11.8 \pm 3.9$ & under 10.0 \\
\hline \multirow{8}{*}{$\begin{array}{l}\text { Chemical } \\
\text { hazards }\end{array}$} & Carbon monoxide $\left(\mathrm{mg} / \mathrm{m}^{3}\right)$ & $58.7 \pm 10.5$ & under 55 \\
\hline & Sulfuric acid $\left(\mathrm{mg} / \mathrm{m}^{3}\right)$ & $1.7 \pm 0.8$ & under 1.0 \\
\hline & Sulfur dioxide $\left(\mathrm{mg} / \mathrm{m}^{3}\right)$ & $5.7 \pm 3.4$ & under 5.0 \\
\hline & Zinc oxide $\left(\mathrm{mg} / \mathrm{m}^{3}\right)$ & $11.8 \pm 2.9$ & under 10.0 \\
\hline & Copper sulfate $\left(\mathrm{mg} / \mathrm{m}^{3}\right)$ & $1.3 \pm 0.5$ & under 1.0 \\
\hline & Magnesium sulfate $\left(\mathrm{mg} / \mathrm{m}^{3}\right)$ & $7.1 \pm 1.3$ & under 6.0 \\
\hline & Xylene $\left(\mathrm{mg} / \mathrm{m}^{3}\right)$ & $445.8 \pm 123.8$ & under 435.0 \\
\hline & Chlorine $\left(\mathrm{mg} / \mathrm{m}^{3}\right)$ & $3.8 \pm 0.7$ & under 3.0 \\
\hline
\end{tabular}


Table 3. Workplace hazards in the "control" group

\begin{tabular}{|c|c|c|c|}
\hline \multicolumn{4}{|c|}{ Type of workplace hazards } \\
\hline & & Measured values & Allowed values \\
\hline \multirow{4}{*}{$\begin{array}{l}\text { Microclimatic } \\
\text { factors }\end{array}$} & \multirow{2}{*}{ Air temperature $\left({ }^{\circ} \mathrm{C}\right)$} & $\begin{array}{c}18.2 \pm 2.4 \\
\text { Winter }\end{array}$ & \multirow{2}{*}{$15-22$} \\
\hline & & $\begin{array}{c}21.8 \pm 8.7 \\
\text { Summer }\end{array}$ & \\
\hline & Air relative humidity $(\%)$ & $53.3 \pm 11.8$ & $30-60$ \\
\hline & Air velocity $(\mathrm{m} / \mathrm{s})$ & $0.4 \pm 1.2$ & under 0.5 \\
\hline & Illumination (Lux) & $94.8 \pm 4.7$ & $80-150$ \\
\hline & Noise $(\mathrm{dB})$ & $57.8 \pm 15.7$ & under 85 \\
\hline & Dust $\left(\mathrm{mg} / \mathrm{m}^{3}\right)$ & $6.8 \pm 3.9$ & under 10.0 \\
\hline & Carbon monoxide $\left(\mathrm{mg} / \mathrm{m}^{3}\right)$ & $23.7 \pm 10.5$ & under 55 \\
\hline & Sulfuric acid $\left(\mathrm{mg} / \mathrm{m}^{3}\right)$ & $0.7 \pm 0.8$ & under 1.0 \\
\hline & Sulfur dioxide $\left(\mathrm{mg} / \mathrm{m}^{3}\right)$ & $0.7 \pm 3.4$ & under 5.0 \\
\hline Chemical & Zinc oxide $\left(\mathrm{mg} / \mathrm{m}^{3}\right)$ & $0.4 \pm 2.9$ & under 10.0 \\
\hline hazards & Copper sulfate $\left(\mathrm{mg} / \mathrm{m}^{3}\right)$ & $0.5 \pm 0.5$ & under 1.0 \\
\hline & Magnesium sulfate $\left(\mathrm{mg} / \mathrm{m}^{3}\right)$ & $4.1 \pm 1.3$ & under 6.0 \\
\hline & Xylene $\left(\mathrm{mg} / \mathrm{m}^{3}\right)$ & $315.8 \pm 14.7$ & under 435.0 \\
\hline & Chlorine $\left(\mathrm{mg} / \mathrm{m}^{3}\right)$ & $1.8 \pm 0.4$ & under 3.0 \\
\hline
\end{tabular}

Table 4. Characteristics of workers in the "case" and "control" group

\begin{tabular}{|c|c|c|c|c|c|c|}
\hline & & \multicolumn{2}{|c|}{$\begin{array}{c}\text { "Case" group } \\
\mathrm{N}=1950\end{array}$} & \multicolumn{2}{|c|}{$\begin{array}{c}\text { "Control" group } \\
\mathrm{N}=1450\end{array}$} & \multirow[t]{2}{*}{$\mathrm{p}$} \\
\hline & & number & $\%$ & number & $\%$ & \\
\hline \multirow{2}{*}{ Gender } & Male & 1347 & 69.1 & 1003 & 69.2 & n.s. \\
\hline & Female & 603 & 30.9 & 447 & 30.8 & n.s. \\
\hline \multirow{5}{*}{ Qualifications } & Laborer & 487 & 24.9 & 310 & 21.4 & $<0.05$ \\
\hline & Skilled workers & 479 & 24.6 & 364 & 25.1 & n.s. \\
\hline & Intermediate & 584 & 29.9 & 422 & 29.1 & n.s. \\
\hline & Advanced & 355 & 18.2 & 241 & 16.6 & n.s. \\
\hline & University level & 45 & 2.3 & 113 & 7.8 & $<0.05$ \\
\hline \multirow{4}{*}{ Matrimonial state } & Unmarried & 491 & 25.2 & 355 & 24.5 & n.s. \\
\hline & Married & 944 & 48.4 & 689 & 47.5 & n.s. \\
\hline & Divorced & 365 & 18.7 & 281 & 19.4 & n.s. \\
\hline & Widower, Widow & 150 & 7.7 & 125 & 8.6 & n.s. \\
\hline \multirow{3}{*}{ Body mass index } & Underweight & 291 & 14.9 & 369 & 25.4 & $<0.05$ \\
\hline & Normal weight & 959 & 49.2 & 700 & 48.3 & n.s. \\
\hline & Overweight and obesity & 700 & 35.9 & 381 & 26.3 & $<0.05$ \\
\hline \multicolumn{2}{|r|}{ Smokers } & 1095 & 56.2 & 810 & 55.9 & n.s. \\
\hline \multicolumn{2}{|c|}{ Alcohol consumption } & 327 & 16.8 & 248 & 17.1 & n.s. \\
\hline \multicolumn{2}{|c|}{ Shift work } & 612 & 31.4 & 457 & 31.5 & n.s. \\
\hline \multicolumn{2}{|c|}{ Work in production quota } & 717 & 36.7 & 534 & 36.8 & n.s. \\
\hline \multicolumn{2}{|c|}{ Night work } & 383 & 19.6 & 287 & 19.8 & n.s. \\
\hline
\end{tabular}

n.s. = difference is statistically insignificant

weight and obesity were more present in the case group, while undernutrition was more present in the control group (Table 4). There was a higher prevalence of neuroses, arterial hypertension, eye diseases, and hearing disturbances in the case group, compared with the control group (Table 5).

\section{Discussion}

There are many factors which influence the occurrence of workplace injuries, and most of the time several factors are involved simultaneously. There is no summation but rather a multiplication of the causes of workplace injuries, and one cause amplifies the others, resulting in a workplace injury. On the other side, if one of the important factors is not involved, an injury is not going to happen. Since there are often combinations of different causes and their interactions, it is difficult to define the main, primary cause of an injury. Involvement of multiple causes in the development of an injury implies a need for a complex 
Table 5. Health conditions and diseases in the "case" and "control" group workers

\begin{tabular}{||l||c|c|c|c|c||}
\hline \hline \multicolumn{1}{||c||}{} & \multicolumn{2}{|c|}{$\begin{array}{c}\text { "Case" group } \\
\mathrm{N}=1950\end{array}$} & \multicolumn{2}{c||}{$\begin{array}{c}\text { "Control" } \\
\text { group } \\
\mathrm{N=140}\end{array}$} & $\mathrm{p}$ \\
\cline { 2 - 6 } & $\mathrm{N}$ & $\%$ & $\mathrm{~N}$ & $\%$ & \\
\hline \hline Neurosis & 292 & 14.9 & 59 & 4.1 & $<0.05$ \\
\hline $\begin{array}{l}\text { Arterial } \\
\text { hypertension }\end{array}$ & 278 & 14.3 & 91 & 6.3 & $<0.05$ \\
\hline Diabetes & 76 & 3.9 & 32 & 2.2 & n.s. \\
\hline Eye diseases & 197 & 13.6 & 71 & 4.9 & $<0.05$ \\
\hline $\begin{array}{l}\text { Gastrointestinal } \\
\text { diseases }\end{array}$ & 119 & 6.1 & 88 & 6.1 & n.s. \\
\hline Lung diseases & 478 & 24.5 & 301 & 20.7 & n.s. \\
\hline Heart diseases & 40 & 2.1 & 24 & 1.6 & n.s. \\
\hline $\begin{array}{l}\text { Hearing } \\
\text { disturbances }\end{array}$ & 337 & 17.3 & 63 & 4.3 & $<0.05$ \\
\hline $\begin{array}{l}\text { Rheumatic } \\
\text { diseases }\end{array}$ & 85 & 4.4 & 59 & 4.1 & n.s. \\
\hline \hline
\end{tabular}

n.s. = difference is statistically insignificant

analysis of all possible causes and search for the most important one. This analysis is a complex task and requires a broad knowledge by the person making the assessment. In order to define adequately the primary cause of a workplace injury, it is necessary to involve a team of experts, including an occupational medicine specialist, occupational safety engineer, technologist, psychologist, social worker, and direct supervisor of the worker. Only after this complex analysis of the place of workplace injury, circumstances of workplace injury, statements by the injured and witnesses regarding the manner in which the injury occurred and other important factors, it is possible to make a conclusion on the cause of an injury.

Therefore, the etiology of workplace accidents is multicausal. The causes could be divided into two groups. The first group of causes are related to a human factor (worker himself), and the second group are the workplace environment factors, including ergonomic, physical, chemical, biological, and social factors. When a human factor is analysed, a very important role play the characteristics of the worker himself, including gender, age, educational level, working experience, adaptation to a new environment and new working process, a need for the production quota to be achieved, a need for personal affirmation at work, psychophysical status and presence of illness, personal lifestyle characteristics, including nutrition, physical activity, smoking habits, alcohol consumption, marital status, etc. $(14,15,16,17)$.

The age of a worker and his working experience are very important factors in the development of workplace injuries, since younger and less experienced workers are more prone to workplace injuries because of their psychological characteristics, including imprudence, lack of self-control, instability, aggressiveness, and more difficult adaptation to the behavioral norms and discipline at workplace $(18,19)$.

Young workers had usually the optimal physical and psychophysiological preconditions, good perceptive and reactive abilities, but nevertheless lacked routine, experience, skills and well defined and differentiated structure of personality which would help them in dealing with complex situations (19). The results of this study also showed that the workers with workplace injuries were younger and had less working experience, compared with the workers without workplace injuries.

In this study, there was a significant difference in the educational level between the workers with and without workplace injury: in the first group, there were more "laborers" (unskilled workers) and less university level workers. This could suggest that the workers in first group were more frequently engaged in physical (or physically more demanding) jobs, or that they were working in worse working conditions. However, it could also indicate some psychological characteristics of workers and a lack of skills or knowledge.

In this group of factors, psychophysical status and presence of illnesses are important worker characteristics. The following groups of people are especially susceptible to workplace injuries: those who are prone to temporary losses of consciousness (syncope, collapse, "fainting"), vertiginous states, those with epilepsy, visual and hearing disorders and diseases, people with neurotic personal characteristics and mental illnesses, people with arterial hypertension and cardiac diseases, lung and gastrointestinal diseases, diabetes and rheumatism $(20,21,22)$. Even the banal illnesses such as headache or toothache can disturb the concentration and awareness of a worker and contribute to the occurrence of workplace injuries (23).

The results of this study also indicated that neuroses, arterial hypertension, eye diseases, hearing disturbances, and overweight and obesity were significantly more present in the group of workers who had workplace injuries, compared with the workers who had not, which was in accordance with the literature data $(24,25,26)$.

Neuroses represent an important risk factor for workplace injuries (27) since the workers with neurotic anxiety have less intellectual efficacy, less concentration and awareness. The workers with neuroses are more instable and in a way more active because they usually try to ameliorate the internal tension, anxiety, and uncomfortable symptoms with a higher degree of activity. The doubt and insecurity can also be a risk factor for workplace injuries. The workers with neuroses could be insecure and passive at workplace, or intensively tense and aggressive, and anxiety rises during work. In workers with neurasthenia, fatigue, tiredness, drowsiness, exhaustion, frequent mood swings, headaches, and sleeping disturbances tend to occur more commonly. Sleeping disturbances and tiredness cause excessive sleepiness during work, which is a common cause of workplace injuries (28). Hysteric and neurotic persons are emotionally immature, egocentric, with an intense urge to dominate, suggestible and hesitant, and therefore could create a risk at their workplace. The working ability of workers who suffer from neuroses is decreased and susceptibility towards injuries is increased also because of the drugs they take to cure their symptoms, 
including sedatives (29). Sedatives could cause temporary fatigue, drowsiness, sleepiness, vertigo and syncope and therefore should be avoided before the beginning of work.

Arterial hypertension, because of its complications, is an important factor which could lead to the occurrence of workplace injuries. The most important complications of arterial hypertension are cerebrovascular disorders, retinal changes and visual disorders, cardiac diseases, psychological disturbances (loss of concentration, distraction, emotional instability, irritability, stubbornness, rigidity, disharmonic attitudes, neurotic behavior), and sleeping disturbances (30, 31, 32), which can influence the safety at work and cause workplace injuries. Additionally, some antihypertensive drugs, especially those which involve a blockade of ganglia, could cause sudden postural hypotension, dizziness, drowsiness, and possible fainting, which can all bring about some serious consequences. There is also evidence that the development of arterial hypertension can be amplified by workplace environmental hazards (noise, vibration, psychophysical stress) (33).

Most of the information from the environment the worker gets via visual and auditive messages, and thus proper functioning of the visual and hearing system is crucial in the prevention of workplace injuries (34).

This study identified overweight and obesity as a risk factor for workplace injuries, which is in accordance with some recent literature data, showing that obesity is related to an increased incidence of workplace injuries $(35,36)$. The mechanism by which obesity increases the odds for injuries is not clearly understood. It is shown that obese people are more prone to injuries of the upper and lower limbs, spine, and locomotor system in general (35). It is proposed that heaviness, instability with movements, loss of speed, inadequate and maladjusted workplace mechanical environment and inadequate and maladjusted self-protection aids for obese people, possibly predispose the obese to injury $(35,37)$. Further, obesity is a risk factor for other diseases, including arterial hypertension, diabetes, chronic obstructive pulmonary diseases, degenerative rheumatic diseases, sleep apnea (and consequential sleepiness during work), which themselves are related to an increased workplace traumatism rate $(36,37,38)$.

According to the literature data (39), undernutrition could also represent a risk factor for workplace injuries. However, the results of this study could not confirm this. On the contrary, an interesting finding from this study was that undernutrition was present in almost quarter of the workers without injury, which was significantly higher than in the group of workers with injury, therefore representing a "protective factor". This requires further studies and assessments.

In the second group, there are the factors related to work itself and workplace environment, including ergonomic aspects of work, stress, lack of social support, and presence of environmental, physical, chemical, and biological workplace hazards $(40,41,42)$.
In this study, there was no difference in work requirements regarding shift work, night work, and work in production quotas between the two examined groups. However, in the group of workers with workplace injuries, there were more "laborers" (unskilled workers) and less university level workers, which could indicate that workers with injuries were more engaged in physical (or physically more demanding) jobs, or that they were working in worse working conditions.

Many studies indicated that intensive psychical and mental labor and effort on work and work overload are related to sleeping disturbances, fatigue and "burn-out syndrome" $(43,44)$. It is known that fatigue related to insufficient resting and sleeping disturbances is one of the most important factors for workplace injuries (45). Fatigue negatively influences movement stability and body posture control (46), causing muscle changes (47) and disturbances in the motor system, manifested as a prolonged reaction time to the acoustic and visual information from the workplace and working process itself (48). Fatigue can disturb the mechanisms maintaining body and movement stability, which can be further aggravated by increased body weight; therefore, obesity aggravates fatigue during prolonged standing and physical work, increasing the risk for workplace injuries $(35,36)$.

Inadequate microclimatic conditions, especially inadequate air temperature and humidity, could negatively influence the psychophysical status of a worker and lead to a workplace injury. If the air temperature is out of the comfort zone range, the difficulties with the thermoregulatory system arise. With a higher temperature, there is capillary vasodilatation and increased circulation rate through the skin and a higher activity of the sweat glands and increased sweating rate, with the aim to increase body heat discharge. There is a feeling of dullness, sleepiness, fatigue, loss of concentration, retardation of reflexes, and disturbance of automatic movements. With a lower temperature, with the aim to prevent body heat release, there are vasoconstriction, lower circulation rate in the periphery, with the consequence of muscle rigidity; the movements slow down and are insecure and finger agility is significantly reduced. Permanently and temporarily increased air circuit velocity could trigger psychophysiological changes, increase heat release and cause muscular spasms, rigidity, myalgia, myositis, and neuritis, which could reduce the working ability too (49). High air humidity causes dullness, dissatisfaction and potentiate pathological personal characteristics (50). All of these influence the safety at work.

Inadequate illumination in the working space is a frequent cause of workplace injuries. It is not only reduced illumination, but also dazzling and blinking lights that constitute important risk factors (51).

Noise is an important factor which causes fatigue in workers and disturbs hearing and understanding of speech and other auditive signals, including warning signals, which can lead to a 
workplace injury. The results of this study agree with the studies which have shown that noise is an important risk factor for injuries (52). Some other studies showed that the level of noise is in a positive correlation with the incidence of workplace injuries (53).

Vapors and gases could also lead to workplace injuries in cases of explosive or flammable substances. Aerosols and dust reduce visibility (54). Very important is also carbon monoxide, leading to hypoxia of the central nervous system, which as a consequence has a faster development of fatigue, impaired estimation and judgment, psychomotor retardation, and reduced coordination of movements (55), influencing the occurrence of workplace injuries. Other chemical hazards detected in this study, including sulfuric acid, sulfur dioxide, zinc oxide, copper sulfate, magnesium sulfate, xylene, and chlorine, cause the changes in the worker nervous system (56) and thus indirectly may cause workplace injuries.

\section{Conclusion}

Hazards originating in the workplace environment, such as inadequate microclimatic factors, noise, dust, air pollution with noxious chemical substances and inadequate illumination, are all important risk factors which could increase the incidence of workplace injuries. Younger age and lack of working experience, as well as the presence of illnesses, including neuroses, arterial hypertension, eye diseases, hearing disturbances, and obesity, could also predispose workers to workplace injuries.

\section{References}

1. Lawrence ER, Halbesleben JR, Paustian-Underdahl $\mathrm{SC}$. The influence of workplace injuries on workfamily conflict: Job and financial insecurity as mechanisms. J Occup Health Psychol 2013; 18: 371-83. [CrossRef] [PubMed]

2. Dong XS, Wang $X$, Largay JA, Sokas R. Economic consequences of workplace injuries in the United States: Findings from the National Longitudinal Survey of Youth (NLSY79). Am J Ind Med 2016; 59:106-18. [CrossRef][PubMed]

3. Diaz AP, Schwarzbold ML, Thais ME, Cavallazzi GG, Schmoeller R, Nunes JC, et al. Personality changes and return to work after severe traumatic brain injury: a prospective study. Rev Bras Psiquiatr 2014; 36: 213-9. [CrossRef][PubMed]

4. Feyer AM, Williamson AM, Stovt N, Driscoll T, Usher $\mathrm{H}$, Langley JD. Comparison of work related fatal injuries in the United States, Australia, and New Zealand: method and overall findings. Inj Prev 2001; 7: 22-8. [CrossRef][PubMed]

5. Jovanović J, Aranđelović $M$, Jovanović $M$. Multidisciplinar aspects of occupational accidents and injuries. Facta Universitatis. Series working and living environment 2004; 2 : 325-34.

6. Park RM, Bhattacharya A. Uncompensated consequences of workplace injuries and illness: Long-term disability and early termination. J Safety Res 2013; 44: 119-24. [CrossRef][PubMed]

7. Mekkodathil A, El-Menyar A, Al-Thani $H$. Occupational injuries in workers from different ethnicities. Int J Crit Illn Inj Sci 2016; 6 :25-32. [CrossRef][PubMed]

8. Merecz-Kot D, Waszkowska M, Wężyk A. Mental health status of drivers-Motor vehicle accidents perpetrators. Med Pregl 2015; 66: 525-38. [CrossRef][PubMed]

9. Dong XS, Wang X, Largay JA, Sokas R. Long-term health outcomes of work-related injuries among construction workers-findings from the National Longitudinal Survey of Youth. Am J Ind Med 2015; 58: 308-18. [CrossRef][PubMed]
10. Skogstad M, Skorstad M, Lie A, Conradi HS, Heir T, Weisæth L. Work-related post-traumatic stress disorder. Occ Med (London) 2013; 63:175-82. [CrossRef][PubMed]

11. Kim J. Depression as a psychosocial consequence of occupational injury in the US working population: findings from the medical expenditure panel survey. BMC public health 2013; 13: 303. [CrossRef][PubMed]

12. Sears JM, Bowman SM, Silverstein BA, Adams D. Identification of work-related injuries in a state trauma registry. J Occup Env Med 2012; 54: 35662. [CrossRef][PubMed]

13. Yazdani A, Neumann WP, Imbeau D, Bigelow $P$, Pagell $M$, Theberge $N$, et al. How compatible are participatory ergonomics programs with occupational health and safety management systems?. Scand J Work Environ Health 2015; 41: 111-23. [CrossRef][PubMed]

14. Jovanović J, Jovanović $M$. Frequency of occupational injuries and the health status of workers, Med Pregl 2004; 57: 536-40. [CrossRef] [PubMed]

15. Jovanović J, Jovanović M. Occupational accidents and injuries: results of a safety preventive programme. Arh Hig Rada Toksikol 2004; 55: 2619. [PubMed]

16. Rios MA, Nery AA, Rios PA, Casotti CA, Cardoso JP. Factors associated with work-related accidents in the informal commercial sector. Cad Saude Publica 2015; 31: 1199-212. [CrossRef][PubMed]

17. Jurado-Gámez B, Guglielmi O, Gude F, Buela-Casal G. Workplace accidents, absenteeism and productivity in patients with sleep apnea. Arch Bronconeumol 2015; 51: 213-8. [CrossRef]

18. Chau N, Dehaene D, Benamghar L, Bourgkard E, Mur JM, Touron C, et al. Roles of age, length of service and job in work-related injury: a prospective study of 63,620 person-years in female workers. Am J Ind Med 2014; 57: 172-83. [CrossRef][PubMed] 
19. Salminen S. Have young workers more injuries than older ones? An international literature review. J Safety Res 2004; 35(5):513-21. [CrossRef] [PubMed]

20. Palmer KT, D'Angelo S, Harris EC, Linaker C, Coggon D. Epilepsy, diabetes mellitus and accidental injury at work. Occ Med (London) 2014; 64: 448-53. [CrossRef][PubMed]

21. Kubo J, Goldstein BA, Cantley LF, Tessier-Sherman B, Galusha D, Slade MD, et al. Contribution of health status and prevalent chronic disease to individual risk for workplace injury in the manufacturing environment. Occup Environ Med 2014; 71: 159-66. [CrossRef][PubMed]

22. Palmer KT, D'Angelo S, Harris EC, Linaker C, Coggon $\mathrm{D}$. The role of mental health problems and psychotropic drug treatments in accidental injury at work. In, 23rd International Conference on Epidemiology in Occupational Health, Utrecht, $\mathrm{NL}$, 18 - 21 Jun 2013; 1pp,28. [CrossRef]

23. Pucci E, De Icco R, Imbriani P, Sandrini G, Nappi G. Accidents and headache. G Ital Med Lav Ergon 2011; 33: 394-8. [PubMed]

24. Lin KH, Chu PC, Kuo CY, Hwang YH, Wu SC, Guo $Y L$. Psychiatric disorders after occupational injury among National Health Insurance enrollees in Taiwan. Psychiatry Res 2014; 219: 645-50. [CrossRef][PubMed]

25. Cantley LF, Galusha D, Cullen MR, Dixon-Ernst C, Tessier-Sherman B, Slade MD, et al. Does tinnitus, hearing asymmetry, or hearing loss predispose to occupational injury risk?. Int J Audiol 2015; 54: 30 6. [CrossRef][PubMed]

26. Kouvonen $A$, Kivimäki $M$, Oksanen T, Pentti J, De Vogli $R$, Virtanen $M$, et al. Obesity and occupational injury: a prospective cohort study of 69,515 public sector employees. PloS one 2013; 8: e77178. [CrossRef][PubMed]

27. Tiikkaja S, Sandin S, Hultman CM, Modin B, Malki $\mathrm{N}$, Sparén P. Psychiatric disorder and work life: A longitudinal study of intra-generational social mobility. Int J Soc Psychiatry 2016; 62: 156-166. [CrossRef][PubMed]

28. Uehli K, Mehta AJ, Miedinger D, Hug K, Schindler C, Holsboer-Trachsler $E$, et al. Sleep problems and work injuries: a systematic review and metaanalysis. Sleep Med Rev 2014; 18: 61-73. [CrossRef][PubMed]

29. Palmer KT, D'Angelo S, Harris EC, Linaker C, Coggon D, Van Staa T. The role of mental health problems and common psychotropic drug treatments in accidental injury at work: a casecontrol study. Occup Environ Med 2014; 71: 308312. [CrossRef][PubMed]

30. Leoncini G, Viazzi F, Storace G, Deferrari G, Pontremoli R. Blood pressure variability and multiple organ damage in primary hypertension. J Hum Hypertens 2013;27: 663-70. [CrossRef] [PubMed]

31. Erden S, Bicakci E. Hypertensive retinopathy: incidence, risk factors, and comorbidities. Clin Exp Hypertens 2012; 34: 397-401. [CrossRef][PubMed]

32. Sahraian A, Mokhtari M, Moaref A, Rezaee V, Moghimi E, Mani A. Hypertensive Patients and Normotensive Individuals: Differences in Anger Inventory. Int Cardiovasc Res J 2015; 9: 216-9.

33. Tomei G, Sancini A, Tomei F, Vitarelli A, Andreozzi $G$, Rinaldi $G$, et al. Prevalence of systemic arterial hypertension, electrocardiogram abnormalities, and noise-induced hearing loss in agricultural workers. Archives of environmental \& occupational health. 2013; 68: 196-203. [CrossRef][PubMed]
34. Palmer KT, D'Angelo S, Harris EC, Linaker C, Coggon D. Sensory impairments, problems of balance and accidental injury at work: a casecontrol study. Occup Environ Med 2015; 72: 195-9. [CrossRef][PubMed]

35. Pollack KM, Sorock GS, Slade MD, Cantley L, Sircar $\mathrm{K}$, Taiwo O, Cullen MR. Association between body mass index and acute traumatic workplace injury in hourly manufacturing employees. Am J Epidemiol 2007; 166: 204-11. [CrossRef][PubMed]

36. Lin TC, Verma SK, Courtney TK. Does obesity contribute to non-fatal occupational injury? Evidence from the National Longitudinal Survey of Youth. Scand J Work Environ Health 2013; 39: 268-75. [CrossRef][PubMed]

37. Schulte PA, Wagner GR, Ostry A, Blanciforti LA, Cutlip RG, Krajnak KM, et al. Work, obesity, and occupational safety and health. Am J Public Health 2007; 97: 428-36. [CrossRef][PubMed]

38. Lombardi DA, Wirtz A, Willetts JL, Folkard S. Independent effects of sleep duration and body mass index on the risk of a work-related injury: evidence from the US National Health Interview Survey (2004-2010). Chronobiol Int 2012; 29: 556-64. [CrossRef][PubMed]

39. Lee SH, Tsai PJ, Lin YT. Work-related incidents among workers in semiconductor industry. Labor Safety and Health Studies Quarterly 2010; 18: 257-67.

40. Salas ML, Quezada S, Basagoitia A, Fernandez T, Herrera R, Parra $M$, et al. Working Conditions, Workplace Violence, and Psychological Distress in Andean Miners: A Cross-sectional Study Across Three Countries. Ann Glob Health 2015; 81: 46574. [CrossRef][PubMed]

41. Shur PZ, Zaitseva NV, Alekseev VB, Shliapnikov DM. Occupational health risk assessment and management in workers in improvement of national policy in occupational hygiene and safety. Gig Sanit 2015; 94: 72-5. [PubMed]

42. Tomei G, Capozzella A, Rosati MV, Tomei F, Rinaldi G, Chighine $A$, et al. Stress and work-related injuries. Clin Ter 2015; 166: e7-e22. [PubMed]

43. Winwood PC, Lushington K. Disentangling the effects of psychological and physical work demands on sleep, recovery and maladaptive chronic stress outcomes within a large sample of Australian nurses. J Adv Nurs 2006; 56: 679-89. [CrossRef] [PubMed]

44. Weber A1, Jaekel-Reinhard A. Burnout syndrome: a disease of modern societies? Occ Med (London) 2000; 50: 512-17. [CrossRef][PubMed]

45. Leger D, Bayon V, Ohayon MM, Philip P, Ement P, Metlaine $A$, et al. Insomnia and accidents: cross-sectional study (EQUINOX) on sleep-related home, work and car accidents in 5293 subjects with insomnia from 10 countries. J Sleep Res 2014; 23: 143-52. [CrossRef][PubMed]

46. Nardone A, Tarantola J, Galante M, Schieppati M. Time course of stabilometric changes after a strenuous treadmill exercise. Arch Phys Med Rehabil 1997; 79: 920-4. [CrossRef]

47. Chabran E, Maton B, Fourment AE. Effects of postural muscle fatigue on the relation between segmental posture and movement. J Electromyogr Kinesiol 2002; 12: 67-79. [CrossRef][PubMed]

48. Balestra C, Duchateau J, HainautK. Effects of fatigue on the stretch reflex in a human muscle. Electroencephalogr Clin Neurophysiol 1992; 85: 4652. [CrossRef][PubMed]

49. Griefahn B, Künemund C, Gehring U. The impact of draught related to air velocity, air temperature and 
workload. Appl Ergon 2001; 32: 407-17. [CrossRef][PubMed]

50. Yildizel SA, Kaplan G, Arslan Y, Yildirim MS, Ozturk AU. A study on the effects of weather conditions on the worker health and performance in a construction site. Journal of Engineering Research and Applied Science. 2016; 4: 291-5.

51. Reinhold K, Tint P. Lighting of workplaces and health risks. Elektronika ir Elektrotechnika 2015; 90: 11-4.

52. Deshaies $P$, Martin $R$, Belzile $D$, Fortier $P$, Laroche $C$, Leroux $T$, et al. Noise as an explanatory factor in work-related fatality reports. Noise Health 2015; 17: 294-9. [CrossRef][PubMed]
53. Yoon JH, Hong JS, Roh J, Kim CN, Won JU.Dose response relationship between noise exposure and the risk of occupational injury. Noise Health 2015; 17: 43-7. [CrossRef][PubMed]

54. Jovanović J. Prevention of occupational accidents. Acta Med Median 2004; 43: 41-55.

55. Jovanović J, Jovanović M, Đorđević D. Professional exposure of drivers to carbon monoxide as a possible risk factor for the occurence of traffic accidents in the road traffic. Vojnosanit pregl 1999; 56: 587-92. [PubMed]

56. Jovanović J, Jovanović M. Neurotoxic effects of organic solvents among workers in paint and laquer manufacturing industry. Med Pregl 2004; 57: 22-5. [CrossRef][PubMed]

\title{
Originalni rad
}

\section{UTICAJ RADNE SREDINE, ZDRAVSTVENOG STANJA I KARAKTERISTIKA RADNIKA NA NASTAJANJE POVREDA NA RADU}

\author{
Jovana Jovanović ${ }^{,}$, Ivana Šarac ${ }^{2}$, Nataša Đinđićc ${ }^{1}$ \\ Stefan Jovanović ${ }^{1}$
}

\author{
${ }^{1}$ Univerzitet u Nišu, Medicinski fakultet Niš, Srbija \\ 2Zavod za zdravstvenu zaštitu radnika Niš, Srbija \\ Kontakt: Jovana Jovanović \\ Bul. dr Zorana Đinđića 81, 18000 Niš, Srbija \\ E-mail: jovana88nis@gmail.com
}

Povrede na radu predstavljaju značajan medicinski, socijalni i ekonomski problem u našoj sredini. Svrha istraživanja je analiza uticaja nepovoljnih uslova radne sredine, starosti, karakteristika i zdravstvenog stanja radnika na pojavu povreda na radu. Eksponovanu grupu je činilo 1950 radnika koji su u periodu od godinu dana (januardecembar 2011.) imali bar jednu povredu na radu. Kontrolnu grupu je činilo 1450 radnika koji u posmatranom periodu nisu imali nijednu povredu na radu, a koji su radili slične poslove (radnici u fabrikama). $U$ obe grupe je obavljeno merenje štetnosti i rizika u radnoj sredini (mikroklimatski faktori radne sredine, osvetljenje, buka, prašina, aerozagađenje, hemijske nokse). Od svih radnika su uzimani podaci o polu, godinama starosti, radnom stažu, školskoj spremi, bračnom stanju, radna, lična, porodična i socijalna anamneza, obavljen je klinički pregled i dopunske analize (laboratorija, ekg, spirometrija, audiometrija i antropometrija). Utvrđena je statistički značajna razlika u češćem prisustvu neuroza, arterijske hipertenzije, bolesti organa čula vida, oštećenja čula sluha i gojaznosti kod radnika eksponovane u odnosu na radnike kontrolne grupe. Štetnosti prisutne u radnoj sredini, starost, radno iskustvo, karakteristike i poremećaj zdravstvenog stanja radnika predstavljaju značajne faktore koji utiču na pojavu povreda na radu.

Acta Medica Medianae 2017;56(4):17-24.

Ključne reči: povreda na radu, buka, aerozagađenje, profesionalni rizik, zdravstveno stanje radnika 